\title{
Republican Liberty and the Pindaric Genealogy of Modern Abstractions
}

\author{
BORIS MASLOV
}

\begin{abstract}
Pindaric odes written around the time of the French Revolution have a penchant for abstractions. Apostrophized Liberty, Fortune, Virtue, and Joy, which replaced the monarch as the ode's addressee, attest to the numinous prehistory of distinctively modern concepts that Reinhart Koselleck termed "collective singulars." In particular, eighteenth-century Pindarics put forward representations of Liberty prevailing over an unenlightened past, which conform to the schema of victorious encounter established in Pindar's epinician odes. The article dwells closely on two ostensibly pro-revolutionary and highly influential texts in the Pindaric mold, Alexander Radishchev's Liberty and Friedrich Schiller's To Joy, which share a concept of freedom that diverges from both the republican and the liberal interpretations.
\end{abstract}

\section{KEYWORDS}

Alexander Radishchev, ancien régime, Friedrich Schiller, genre, liberalism, Pindaric ode, republicanism

\section{Literary History as a Challenge to the History of Concepts}

The history of the concept of liberty has a very familiar plotline. Presaged in Greco-Roman antiquity, triumphantly proclaimed at the time of the American and French Revolutions, and globally dominant from then on, liberty is a trademark of Western modernity. The present contribution is an attempt to rethink this narrative by adopting an unusual methodological perspective, that of literary history. I will define Liberty and kindred abstractions by their function within a poetic genre-the Pindaric ode-whose structure, to a large extent, dictates the meaning of the text. While the history of political thought tends to regard its objects of study as pieces of intellectual property acquired, redesigned, and disseminated by individual thinkers, the history of poetic genres attends to lasting structures that set the "horizon of expec-

The author is grateful to the journal's two anonymous referees as well as to numerous colleagues who offered their criticisms and reactions to the arguments presented in this article. 
tations," shared by authors and readers and open to very limited innovation. ${ }^{1}$ For this reason, the transformation of a poetic genre with a prominent political function, such as the Pindaric ode, always indicates profound historical change. What remains the same in such a genre, even as it is transformed, attests to continuities that are no less telling and deserving of exploration.

A close analysis of the early modern and eighteenth-century Pindaric ode will enable us to offer an alternative classical genealogy of liberty, a concept that, in light of Quentin Skinner's work, has been viewed as a mainstay of the republican tradition reaching back, via Thomas Paine and Machiavelli, to Livy. ${ }^{2}$ In a phrase applied by Jean Starobinski to the concept of civilization, liberty came to represent "an epiphany of the sacred in the modern age." ${ }^{3}$ In contrast to civilization, however, Liberty inherited this function from classical allegories. To elucidate the way in which poetic abstractions come to inform political ones, and vice versa, this article proposes a rapprochement between Historical Poetics, a theory of persistence of literary forms originally formulated by Alexander Veselovsky, and historical semantics, or Begriffsgeschichte, a method of analyzing conceptual structures developed by Reinhart Koselleck.

Where Anglo-American intellectual history, exemplified by Skinner's studies, and the German school of Begriffsgeschichte disagree is on the question of conceptual continuity. Do abstract ideas such as freedom, justice, or peace operate similarly across historical periods and media? While most historians of political ideas assume a positive answer, Koselleck makes a case that modern "collective singulars" such as history, liberty, or socialism, which emerged in the century around the French Revolution, have a distinctive structure: they apply universally, rather than to particular social groups; replace actual experience with expectation; and conjure up engrossing politi-

1. For this notion, see Hans Robert Jauss, "Literary History as a Challenge to Literary Theory," trans. Elizabeth Benzinger, New Literary History 2, no. 1 (1970): 7-37. The point is similar to that made by Arthur Lovejoy: the history of ideas should explore "manifestations of specific unit-ideas in the collective thought of large groups of persons, not merely in the doctrines or opinions of a small number of profound thinkers or eminent writers." Arthur Lovejoy, The Great Chain of Being: A Study of the History of an Idea (Cambridge, MA: Harvard University Press, 1936), 19.

2. On the republican (or "neo-Roman") tradition of liberty, see J. G. A. Pocock, The Machiavellian Moment: Florentine Political Thought and the Atlantic Republican Tradition (Princeton, NJ: Princeton University Press, 1975); Quentin Skinner, Liberty before Liberalism (Cambridge: Cambridge University Press, 1998); on this tradition's classical roots, see Quentin Skinner, Hobbes and Republican Liberty (Cambridge: Cambridge University Press, 2008), 44-72.

3. Jean Starobinski, Blessings in Disguise: Or, the Morality of Evil, trans Arthur Goldhammer (Cambridge, MA: Harvard University Press, 1993), 20. 
cal visions of the future. ${ }^{4}$ The emergence of this modern attitude to historical time is aided by a "philological event" of momentous significance: the rise of a new class of words, whose meaning pertains to all yet whose form is singular. ${ }^{5}$

The history of the ode, on the one hand, bears out Koselleck's argument, attesting to the promotion of abstractions to the center of odic poetics at the end of the eighteenth century. On the other hand, more intriguingly, the inherited structure of this genre complicates the notion that "collective singulars" are unique to modernity. Modern Pindaric odes offer insights into both the radical transformation of the conceptual apparatus analyzed by Koselleck, its preconditions in the culture of the ancien régime, as well as, more generally, what we might call the anthropological status of modern political abstractions. Ever since Veselovsky's work on comparative poetics of preliterate cultures, Historical Poetics has had an interest in uncovering elements-images, devices, motifs-whose recurrence cannot be explained by borrowing; stored in a kind of cultural unconscious, these elements reemerge periodically when called upon by a "popular-poetic demand, in response to an urgent call of the times." Any account of formal continuity or similarity in literature must thus be triply historical: attentive to the immediate context of the text, aware of the literary tradition behind it, and cognizant of the typologically widespread and potentially universal social need that may inform it.

Supplying historical semantics with the lens of Historical Poetics means shifting its focus away from Koselleck's interest in the political and social history of the eighteenth and nineteenth centuries to the kind of conceptual longue durée explored by Hans Blumenberg in his inquiry into European modernity's "work on myth."7 Essentially conservative, genres, in Mikhail

4. So, for example, plural liberties (assigned to particular social groups in a statusbased society) are transformed into universal Liberty. See esp. Reinhart Koselleck, Futures Past: On the Semantics of Historical Time (New York: Columbia University Press, 2004), key formulations at 35, 50, 80; Reinhart Koselleck, Begriffsgeschichten: Studien zur Semantik und Pragmatik derpolitischen und sozialen Sprache [Conceptual histories: Studies on semantics and pragmatics of political and social language] (Frankfurt: Suhrkamp, 2006), 306-308. For a critique of the notion of "collective singulars" as uniquely characteristic of European modernity, see Nikolay Koposov, "Collective Singulars: A Reinterpretation," Contributions to the History of Concepts 6, no. 1 (2011): 39-64, https://doi .org/10.3167/choc.2011.060103.

5. Koselleck, Futures Past, 35.

6. Alexander Veselovsky, "From the Introduction to Historical Poetics: Questions and Answers," in Persistent Forms: Explorations in Historical Poetics, ed. Ilya Kliger and Boris Maslov (New York: Fordham University Press, 2016), 39-64, here 60.

7. For an "anthropological" approach to European modernity, see Hans Blumenberg, Work on Myth (Cambridge, MA: MIT Press, 1985); Bruno Latour, We Have Never Been 
Bakhtin's phrase, carry within them "undying elements of the archaic." Indeed, once the modern condition is cast as an anthropological datum, literary texts become indispensable, both as evidence of the natives' (whether the premoderns' or the moderns') pervasive conceptions of the world, and as historical mediators that enable us to recognize these conceptions as, to a degree, our own. From this perspective, the watershed "philological event" of singularization that once and for all separated the moderns from the premoderns appears to be a mirage. Instead, literary history invites us to ponder why certain types of abstractions endure over centuries and millennia, even as they are variously employed within different ideologies or epistemes.

Inasmuch as literary genres not only survive for lengthy periods of time but also easily cross linguistic and national boundaries, they provide readymade yet pliable frames for conceptualizing historical and political experience. Reflecting on the effect of genre on the reader, Hans Robert Jauss remarks, "A literary work, even if it seems new, does not appear as something absolutely new in an informational vacuum, but predisposes its readers to a very definite type of reception by textual strategies, overt and covert signals, familiar characteristics or implicit allusions." In literature, words do not exist as part of a commonly shared political language or as conceptual tools freely available to social agents to make sense of the world. Instead, they are elements within systems of diction that are determined by the kind of discourse in which they are employed. Epic, for example, dictates its own terms and conceptual oppositions, which are quite different from those found in the pastoral or in the realist novel. ${ }^{10}$

Perhaps the best guide to the pan-European royalist imaginary in the early modern period is the Pindaric ode, a poetic medium modeled on Pindar's epinikia (victory odes) composed in the fifth century BCE. In the European tradition of lyric, the Pindaric ode was contrasted with the more meditative, individual-centered (Horatian) and lighthearted, sensual (Anacreontic) varieties of poetic utterance. If poets wished to address the

Modern (Cambridge, MA: Harvard University Press, 1993). Zhivov's studies on the Enlightenment "state mythology" in Russia set a methodological precedent for conceiving of classical legacy in politics in relation to the longue durée of literary genres; see Boris A. Uspensky and Victor M. Zhivov, "Tsar and God" and Other Essays in Russian Cultural Semiotics (Boston: Academic Studies Press, 2012), 191-257.

8. Mikhail Bakhtin, Problems of Dostoevsky's Poetics, ed. and trans. Caryl Emerson (Minneapolis: University of Minnesota Press, 1984), 106.

9. Jauss, "Literary History," 12.

10. See esp. Mikhail Bakhtin, "Forms of Time and of the Chronotope in the Novel: Notes toward a Historical Poetics," in The Dialogic Imagination, trans. Caryl Emerson an Michael Holquist (Austin: University of Texas Press, 1981), 84-258; on epic, see also David Quint, Epic and Empire: Politics and Generic Form from Virgil to Milton (Princeton, NJ: Princeton University Press, 1993). 
community within the brief compass of a lyric poem, while using the highest registers of inherited language, they had recourse to the Pindaric. ${ }^{11}$ This article was prompted by the following questions: What happened to the Pindaric at the time of the ascendancy of anti-monarchical sentiment? How does one go about composing a republican ode in the Pindaric vein? And what can the poets' work on the ideological refurbishing of Pindar tell us about the socio-symbolic form of modern republicanism itself? After laying out my evidence for viewing the early modern Pindaric poetics as structurally expressive of the politics of the ancien régime, I focus on the eighteenth century, when poets across Europe sought to remold this poetic medium, and then present detailed analyses of two particularly influential odic experiments. Finally, I ponder what the persistent elements of the Pindaric ode can teach us about the numinous quality of Liberty in the modern world.

\section{A Poetics of the Ancien Régime}

The principal discursive vehicle of European monarchical regimes-which here, at the cost of considerable but heuristically imperative simplification, are subsumed under the name ancien régime-were texts composed for occasions deemed to be politically important, often orally performed or otherwise presented to the sovereign addressee. These occasions included military victories, royal travels and homecomings, and all kinds of dynastic events including births, marriages, and deaths. These texts are often summarily described as panegyrics and dismissed as ideologically complicit propaganda. This dismissal is founded on a misinterpretation. Propaganda implies propagation and dissemination of ideas, whereas panegyrics, in general, circulate within a narrow sphere of an elite audience. ${ }^{12}$ Furthermore, the very predictability of panegyric bespeaks its nature as an established

11. On the European Pindaric ode, see William Fitzgerald, Agonistic Poetry: The Pindaric Mode in Pindar, Horace, Holderlin, and the English Ode (Berkeley: University of California Press, 1987); John T. Hamilton, Soliciting Darkness: Pindar, Obscurity, and the Classical Tradition (Cambridge, MA: Harvard University Press, 2003); Stella P. Revard, Pindar and the Renaissance Hymn-Ode: 1450-1700 (Tempe: Arizona Center for Medieval and Renaissance Studies, 2001); Martin Vöhler, Pindarrezeptionen: Sechs Studien zum Wandel des Pindarverständnisses von Erasmus bis Herder [Pindar receptions: Six studies on the transformation of the understanding of Pindar from Erasmus to Herder] (Heidelberg: Winter, 2005).

12. On discourses of elite self-legitimation in autocratic regimes, see Stephen Orgel, The Illusion of Power: Political Theater in the English Renaissance (Berkeley: University of California Press, 1975); Sabine MacCormack, Art and Ceremony in Late Antiquity (Berkeley: University of California Press, 1981); Richard Wortman, Scenarios of Power: Myth and Ceremony in Russian Monarchy (Princeton, NJ: Princeton University Press, 1995). 
genre that reflects, constructs, upholds, and reiterates a worldview that lies at the heart of the ancien régime.

A poetics, etymologically, refers to how an object is made or constructed, and an effort to understand the poetics of the ancien régime demands close scrutiny of images, metaphors, tropes, and myths that are integral to panegyrical genres. As a socio-symbolic form, a genre represents sedimented sociopolitical content. Inasmuch as it retains deeply entrenched conceptual and more narrowly ideological elements, the longevity of a genre and its capacity for being exported becomes the best token of the vigor of the worldview it communicates. In this sense, literary genres testify to the historical longue durée more compellingly than the thought of any given individual political theorist or philosopher. The challenge is to uncover the underlying semantic structure of genre, which is embedded in but also extends beyond style-beyond verbal register, stanzaic form, prosodic features, and so on. This essentially mythopoeic ("myth-creating") form largely dictates the text's political content, as it incessantly, through each textual instantiation of genre, suggests that a particular kind of story can explain the world.

A Pindaric is typically centered on the narrative of an isolated encounter that resulted in the success of the addressee, a victory of one sort or another; the genre's focus is as much on the individual actors as on the community they represent. As a result, the narrative of the victorious overcoming tends to assume the shape of a myth that celebrates the constitution of the Self in opposition to the Other-a political antagonist, a foreign enemy, an elemental or beastly force. What the Pindaric ode shares with any rhetorical panegyric is the anchor in a particular occasion. That occasion need not coincide with the encounter that is being narrated and subsumed into myth, but it is usually specified in the text and coincides with the text's actual or imaginary performance. For instance, the monarch's return to the capital (adventus) frequently prompts a narrative of an antecedent battle. Crucial to the genre is its double pragmatic anchoring in the life of a society and in a motivating event that makes the body politic visible and representable.

A particular marker of the genre is its prominent speaking persona. Whether individualized or inclusive of a wider community and approximating the panegyrical "we," it is typically staged as the beneficiary of the event that motivates the text. As a representative of the society, the speaker sings the praise of and renders thanks to the sovereign primarily because the latter embodies the community in its active, agentive hypostasis. In a Pindaric ode, the sovereign is never merely the poet's patron but rather a function in the "communal drama" enacted by the poem. ${ }^{13}$ In the premodern world, the

13. The term "communal drama" is applied to Pindar's epinikia in Leslie Kurke, The Traffic in Praise: Pindar and the Poetics of Social Economy (Ithaca, NY: Cornell University Press, 1991), 257-262. 
heroic individual is often a trope for historical agency: as Marshall Sahlins argues, in "heroic polities," in which "history is anthropomorphic in principle," the king is "the condition of the possibility of community." 14

The European Pindaric ode is loosely based on the precedent of Pindar's epinician (victory) odes for athletes or sponsors victorious at one of the Panhellenic Games; those odes were commissioned by the family of the victor and performed by a chorus, usually as part of the celebration of the athlete's return to his home polis. What makes these texts distinctive-and what explains the difference between early modern Pindarics and rhetorical encomia-is the extent to which they rely on the conventions of communal hymn. In particular, it is far more common for a victory ode by Pindar to begin with an address to a deity or a personified abstraction than with an address to the honoree..$^{15}$ The hymnic tradition also dictates the inclusion of a mythic narrative that is relevant for the civic identity at large, rather than allegorically applicable to the particular victor.

The early modern Pindaric poetics thus integrates crucial elements of the ideology of the ancien régime: a rhetoric of second-person address, equally applicable to God and to the sovereign and thus implying a fundamental homology between the positions of the subject in the religious and the political order; an event-based model of history, which assigns a heroic agency to the political actor, and a passive role-limited to spontaneous emotional response-to the multitude; an occasion-driven mode of discursive intervention in the political world, whereby the text is necessarily prompted by a particular event.

In its embrace of the status quo, the myth of the early modern Pindaric may be said to be inherently anti-republican in that it pits order, harmony, and tranquility against chaos, discord, and strife; this binary opposition is buttressed by mythical exempla, historical precedents, and traditional imagery. The underpinning narrative ultimately derives from the myths of the civilizing hero (paradigmatically, Heracles), frequently used in Pindar's odes. The subduing of the monstrous and the unknown as an act of creation of the political cosmos, brought about by a solitary, divinely sanctioned agent, becomes the archplot of monarchical poetics. For example, as Stella Revard shows, Heracles's youthful feat of smothering the snakes, celebrated in Pindar's Nemean 1 , became one of the most frequent mythical comparanda for infant or young princes addressed in early modern Pindaric odes. ${ }^{16}$ Another common reference point was the myth of the giants' rebellion subdued by the forces of $\mathrm{Ze}$ us's benign regime, based on Pindar's influential Pythian 1, which imagines

14. Marshall Sahlins, Islands of History (Chicago: University of Chicago, 1985), 35-36.

15. Boris Maslov, Pindar and the Emergence of Literature (Cambridge: Cambridge University Press, 2015), 307-311.

16. Revard, Politics, 11, 133-138, 165-169. 
the teeming discontent of Typho, chained underneath the mountain, to be visible in the eruptions of Aetna. ${ }^{17}$ Once civil strife-the populace in its "active," rather than passive hypostasis-is analogized to such monstrous, chaos-inducing creatures, a potent antidemocratic discourse is in place. ${ }^{18}$

The most influential form of the Pindaric in Britain was molded by Abraham Cowley in his Pindarique Odes (1656). This collection arrived in the wake of Andrew Marvell's employment of the Pindaric ode to praise Oliver Cromwell in "The First Anniversary of the Government under His Highness, the Lord Protector" (1654), a text that redeploys many of the traditional topoi to praise Cromwell as a heroic figure, thus falling short of effecting a major departure from the traditional poetics of power. ${ }^{19}$ Among the aspects of this poem that can be said to anticipate the republican odes of the late eighteenth century is the emphasis on Cromwell's future-oriented disposition ("who in his Age has always forward prest"); Marvell still, however, places his hopes in the leadership of a single individual and invites "a seasonable People" to "bend to his, as he to Heaven's will."

Cowley's odes would provide a specific model for Pindarics written for British monarchs until the early eighteenth century, yet Pindaric monarchical poetics was, in fact, pan-European. By way of Poland, which mediated the Latin poetic culture to the East, it reached Muscovy in the late seventeenth century. ${ }^{20}$ Feofan Prokopovich's Epinikion, written on the occasion of the Russian victory over Sweden in the battle of Poltava in 1709, is a particularly eloquent token of the global reach of this poetic form. In the Epinikion, the monarch (Peter the Great) and God are one and the same agent, whose beneficent activity on behalf of the community is rendered conspicuous in a concrete event of victorious overcoming. What Peter the Great faced at Poltava was not only foreign invasion but also civil rebellion that involved a part of the Ukrainian nobility. The subduing of the enemy, explicitly compared to a beast, thus affirmed the integrity of the body politic. In a different poem,

17. Ibid., 10, 106-121, 192.

18. Ibid., 18-19, 57, 159, 273-274.

19. Cf. Stella Revard, "Building the Foundations of a Good Common-Wealth: Marvell, Pindar, and the Power of Music," in "The Muses Common-Weale": Poetry and Politics in the Seventeenth Century, ed. Claude J. Summers and Ted-Larry Pebworth (Columbia: University of Missouri Press, 1988), 177-190. Revard's argument directly linking the First Anniversary Ode to Pindar's Pythian 1, however, is not compelling. For a subtle analysis of Marvell's revision of the Horatian ode along "republican" lines in "An Horatian Ode upon Cromwell's Return from Ireland," see David Norbrook, "Marvell's 'Horatian Ode' and the Politics of Genre," in Literature and the English Civil War, ed. Thomas Healy and Jonathan Sawday (Cambridge: Cambridge University Press, 1990), 147-169.

20. See Boris Maslov, "Why Republics Always Fail: Pondering Feofan Prokopovich's Poetics of Absolutism," ВИВЛІОӨИКА: E-Journal of Eighteenth-Century Russian Studies 2(2014): 24-46. 
Prokopovich speaks of republican "civil hell," ${ }^{21}$ glimpsed during the failed attempt at an aristocratic takeover in 1730. Republicanism, as Prokopovich recognized, posed an existential threat to all those conceptual patterns of the ancien régime that the early modern Pindaric encapsulated: the alignment between political authority and divine power, an individual heroic actor that makes history on behalf of all, a community united in thankful remembrance of the victorious event of its self-constitution.

\section{The Pindaric and the Rise of Modern Concepts}

It may appear that the arrival of modernity spelled the end of the Pindaric poetics of the ancien régime. The demise of the event-based model of history, which deprived poetic discourse of its contextual motivation, had to do with a major shift in the perception of historical time. The centrality of the event that furnishes the occasion for the poetic intervention in the world is a fundamental aspect of premodern poetics. Dmitri Likhachev has suggested that the lack of awareness of historical change entails a view of social and political order as fundamentally immutable: Medieval chronicles, for instance, fail to comment on social and economic history, but instead operate in the temporality of "events or incidents broadly construed." 22 Hannah Arendt linked the appearance of the idea of process to the concomitant decline in the significance of individual act. ${ }^{23}$ In the modern world in which historicism has penetrated all aspects of the social and even the natural world, and in which change is incremental and not locatable in any given moment of time, a singular event is stripped of its former significance. Linked to the rise of processual thinking, major sociopolitical transformations made nonsense of the entrenched conceptualization of political agency, which could no longer be ascribed to a single individual. Finally, the alignment of the two "addressees"-God and the sovereign-could no longer be maintained, as direct divine involvement in human history was increasingly in doubt.

The difficulty of adapting the Pindaric ode to a republican stance-a difficulty in part indicative of the overall marginalization of classical literary genres in the modern era-can be viewed as a symptom of the momentous shift of the political paradigm occurring between 1750 and 1850. One strat-

21. Ibid.," 44.

22. Dmitri Likhachev, Poetika drevnerusskoi literatury [Poetics of Old Russian literature], 3rd ed. (Moscow: Nauka, 1979), 209.

23. Hannah Arendt, "Concept of History: Ancient and Modern," in Between Past and Future: Six Exercises in Political Thought (New York: Viking, 1961), 41-90, esp. 63-65. On the "new style of thinking" that emphasized the ideas of process and multitude, see Koposov, "Collective Singulars," 52-59. 
egy of reforming the Pindaric that was used by poets across Europe in the eighteenth century was to foreground abstract concepts as personifications, which came to replace the solitary agents of heroic narrative. The massive restructuring of the conceptual apparatus in the century around the French Revolution, as Koselleck has shown, went along with the emergence of a new type of historical consciousness, intimately linked to a new kind of politics. ${ }^{24}$ Concepts now become abstract ideals projected into the future, and history is seen as progress, more or less violent, toward this future. Modern texts may be expected to employ such abstractions in their retellings of the story of emancipation, innovation, and rupture. Furthermore, the proximity of abstract concepts such as Peace and Liberty to female allegories of the nation (Britannia, Columbia, Germania, Marianne) points to the ease with which they can be appropriated by the national state as foci of collective identity. ${ }^{25}$

The prominence of abstract concepts in poetic texts that aspire to political relevance in this period is, in short, hardly surprising. It has not been noted, however, that it was also licensed by the genre of the Pindaric ode, which always favored allegorizing use of concepts. While a trust in concepts characteristic of the Enlightenment is also indebted to the Renaissance penchant for allegories and emblems, Pindar's epinikia provided the original resource for creative employment of abstractions in lieu of hymnic divine addressees. Perhaps most influential in this regard was the opening of Pythian 8. I quote J. L. Girdlestone's early nineteenth-century translation of the opening passage, bracketing the translator's additions to the original:
Sweet Peace, soft-bosom'd child
Of Justice, ever-mild,
Exalter of great states, whose [lovely] hand
Unlocks the [secret breast]
Of Council, [in deep rest
Grim] War [composes with enchanted band];
The Pythian conqueror receive

24. Koselleck, Futures Past; Reinhart Koselleck, "Hinweise auf die temporalen Strukturen begriffsgeschichtlichen Wandels" [Indications of the temporal structures of conceptual historical change], in Begriffsgeschichte, Diskursgeschichte, Metapherngeschichte [Conceptual history, history of discourse, history of metaphors], ed. Hans Erich Bödeker (Göttingen: Wallstein, 2002), 31-47.

25. On Britannia and Columbia: Marina Warner, Monuments and Maidens: The Allegory of the Female Form (London: Weidenfeld \& Nicolson, 1985), 38-60 and 13; Marianne: Maurice Agulhon, Marianne into Battle: Republican Imagery and Symbolism in France, 1789-1880 (Cambridge: Cambridge University Press, 1981); Germania: Bettina Brandt, Germania und Ihre Söhne: Repräsentationen von Nation, Geschlecht und Politik in der Moderne [Germania and her sons: Representations of nation, gender, and politics in the modern age] (Göttingen: Vandenhoeck, 2010). 
[And for his brow thy choicest laurels weave].

[While blooms the season fair], well knows [thy heart]

All blessings to enjoy, all blessings to impart.

When Rage tempests the soul

[And boist'rous billows roll]

Thy pow'rful [beams] break forth upon the foe,

[No more the sails of Pride

Swell o'er the calmed tide],

[Mad] Insolence beneath the flood sinks low:

But ne'er Porphyrion's savage breast,

[Whose law was force,] thy gentle pow'r confest.

Yet soon he saw, his mad attempts how vain;

The voluntary gift is far superior gain:

Time and avenging Pow'r confound

Pride [and her lawless sons];

The vast Typhoeus falls to ground,

Jove's vollied thunder stuns

His hundred giant-heads; Apollo's dart

Pierces the tyrant-monster [to the heart] ${ }^{26}$

Girdlestone's translation gives a sense of how Pindar was read at the end of the eighteenth and in the early nineteenth century. Particularly noteworthy is the penchant for personifying concepts. Taking the cue from the opening address that describes-using a figure of genealogical metaphor ${ }^{27}$-Peace as a daughter of Justice, the English version ascribes agency, and in some cases personalizing attributes, to "Council," "Grim War," "Rage," "Mad Insolence," and "Time," which in Pindar's text are not personified. The effort to remold mythology into an encounter between bare concepts-an encounter that only partially yields to narrativization and thus to allegorical construal-is nevertheless clearly licensed by Pindar's original. The figure of Peace (Hesykhia), in Pindar a close relative of Harmonia, evokes the benign workings of the cosmos under the Olympian gods, whose reign was preceded by general lawlessness overseen by natural monsters. ${ }^{28}$ The surprising aspect of this passage is that power, or "physical force" (bia), is attributed to Peace itself, as one of its modi operandi. The quoted passage thus attests to the substitution of an abstract concept for the heroic agent subduing the monsters of the past. This move will prove important for poets seeking to remold the Pindaric in the eighteenth century.

26. Pindarus, All the Odes of Pindar, trans. J. L. Girdlestone (Norwich: Bacon, 1810 [?]), 191-192.

27. On genealogical metaphors in Pindar, see Maslov, Pindar, 146-155.

28. Cf. Elroy Lorraine Bundy, "Hesychia in Pindar" (PhD. diss., University of California, Berkeley, 1954). 
The topos of Peace-describing the blissful stasis to be enjoyed by all but made possible by the valorous activity of the individual monarch-was deeply engrained in the mythological form of the early modern Pindaric ode beginning with its invention by Pierre Ronsard. ${ }^{29}$ As a token of the broad impact of this topos, here is the opening of Mikhail Lomonosov's 1747 ode for an anniversary of the enthronement of the Russian empress Elizabeth, Peter the Great's daughter:

The joy of kings and earthly kingdoms,

Beloved peace,

The bliss of the countryside, the bullwark of cities,

How advantageous and lovely you are $!^{30}$

There is no reason to posit a direct intertextual link between this passage and Pindar's Pythian 8. Indeed, the similarity between the two texts is even more valuable if it reflects an entrenched ideological poetics propagated across Europe along with the genre of the Pindaric ode.

Despite the availability of the figure of an address to a personified concept, early modern Pindarics tend to retain their anchor in the occasion. Lomonosov's poem is entitled "An Ode on the Day of the Enthronement of Her Majesty Empress Elizabeth Petrovna in 1747"; it is not "An Ode to Peace." Yet, the transformation of the ode-away from a concrete event and toward abstract concepts-was underway in the first half of the eighteenth century in Western Europe, betokening broader decontextualization of literary production. Poets such as Jean-Baptiste Rousseau in France and William Collins in Britain addressed odes to the abstract entities Paix and Peace. Alongside the gradual loss of pragmatic anchoring, the Pindaric comes to favor metaphysical or sociopolitical reflection at the expense of narrative. ${ }^{31}$

Jean-Baptiste Rousseau's A la Fortune (1716) was one of the most celebrated eighteenth-century philosophical odes, well-known throughout Europe. ${ }^{32}$ Constructing a poem around the address to "Fortune" has prec-

29. On this topos in the European Pindaric tradition, see Revard, Politics, 50, 59, 78$79,96$.

30. Mikhail Lomonosov, Polnoe sobranie sochinenii [Complete collected works], vol. 8 (Moscow: Izd-vo Akademii nauk, 1959), 196. All translations are mine unless otherwise noted.

31. Uses of the Pindaric form in twentieth- and twenty-first-century poetry manifests its potential to embrace gnome-ridden commentary on the human condition (Osip Mandelstam's “The Horseshoe Finder") or even to abandon the concrete entirely in the name of conceptual generality (Robert Pinsky's "Ode to Meaning”).

32. We happen to know that this poem was a subject of conversation between Klopstock and Wordsworth in 1799. William Wordsworth, The Prose Works, ed. Warwick J. B. Owen and Jane W. Smyser, vol. 1 (Oxford: Clarendon Press 1974), 93. 
edents in Pindar's Olympian 12 and Horace's Ode 1.35, but Rousseau's text departs from the conventions of the classical ode in that it almost completely eschews narration. The object of the text's polemic is nevertheless unmistakable: it is the poetics of individual sovereignty associated with the Pindaric ode (and other genres tied to the ancien régime, such as epic and military historiography). Rousseau rejects the model of historical agency that casts the monarch as an emblem of the community, instead pitting them against each other: "Is it not the misfortune of men that makes for the virtue of great kings?” (Est-ce donc le malheur des hommes / Quifait la vertu des grands rois?) The Enlightenment no longer allows for the equation of a general's military success with the self-constitution of a community. It is destruction pure and simple: "the glory" of the monarchs is "fecund in ruins" (leur gloire, féconde en ruines).

While unsettling a fundamental element of the heroic ideology, Rousseau does not, in fact, voice a republican sensibility. In the ode, a didactic tendency predominates, placing it in the tradition of advice to rulers, going back to medieval "mirrors for princes." The civil violence of Mark Anthony and Lepidus is condemned, but Augustus is praised for building an empire that is heureux et juste. The Roman emperor Titus stands, next to Socrates, as a model for a good king. In a further moralizing move, Wisdom, which the ruler is invited to acquire, is said to triumph over both the gods and fortune. ${ }^{33}$ In another Pindarizing ode ostensibly addressed to an abstract concept but in fact driven by a more specific panegyrical intent, A la Verité (1766), Voltaire takes issue with Rousseau's dismissal of military valor. Addressing the "illustrious plagues of the earth" (illustres fléaux de la terre), Voltaire proclaims: "I detest you, but I admire you. Guard that eternal power that glory has over our spirits! It is to tyrants who lack courage that I owe nothing except horror and contempt" (Je vous hais; mais je vous admire: / Gardez cet éternel empire / Que la gloire a sur nos esprits; / Ce sont les tyrans sans courage / A qui je ne dois pour hommage / Que de horreur et du mépris). ${ }^{34}$

The poet who deserves the most credit for reforming the Pindaric ode into a republican medium is William Collins, who exerted a strong influence on the British Romantics, as well as the German poets of the Sturm und Drang period. ${ }^{35}$ His Ode to Liberty is an obvious precedent for Shelley's poem of the

33. Jean-Baptiste Rousseau, Oeuvres, ed. Antoine de Latour (Paris: Garnier, 1869), $114-120$.

34. Voltaire, Oeuvres completes, vol. 8 (Paris: Garnier, 1877-1885), 482.

35. Wordsworth, an admirer of Collins, discussed him with Klopstock, who observed that "he had read [Collins's odes] with pleasure." Quoted in Wordsworth, Prose Works, 94. See Sandro Jung, "Wordsworth and Collins," ANQ 22, no. 1 (2009): 19-24, here 19. On Wordsworth's own uses of freedom, a concept he would, in his conservative phase, align with "order," see Carl R. Woodring, "On Liberty in the Poetry of Wordsworth," 
same name, which is also inspired directly by Pindar. ${ }^{36}$ The Ode to Liberty (1746), self-consciously Pindaric in its metrical and stanzaic irregularity, is loosely based on James Thomson's long didactic poem Liberty, where the republican ideal is conceived, in the Whig spirit, as progress of "Independent life; integrity in Office; and, ... A Passion for the Common-weal" (5.121-3) conjoined. ${ }^{37}$ While Thomson has an overly benign vision of Liberty, it is associated in Collins with a violence that is mitigated only by the appearance of the figure of Concord or Peace at the end of the poem..$^{38}$ Collins recasts the "progress" of Liberty through different nations as the fragmentation of a classical republican model so that "some remnants of her strength were found" "midst the scattered states around"-including the Italian republics, Holland, and Switzerland.

Its eventual installation in Britain is imagined as a blending of the classical republican tradition with a native British ("Gothic") democracy. The Pindaric archplot of order imposed on chaos is displaced onto natural history: Collins evokes a piece of scientific knowledge, that France and the British Isles once formed one continent before a forceful separation: "this pillared earth ... in thunders dread was push'd aside," thereby creating the British Isles, Liberty's "loved ... last" abode. Collins's Ode to Liberty showcases the challenge of combining a republican political sensibility with an inherited ideological poetics. His compromise solution was, while omitting the violent individual agency of the monarch, to foreground its positive correlate, Peace/Concord enjoyed by the community. How this state of happy self-identity and equilibrium was to be achieved remained uncertain, and ultimately up to an inscrutable logic of the progress of a divinized abstract agent (Liberty), which supersedes the classicized Christian God of early modern Pindarics.

Alexander Pushkin's Volnost' (Liberty, 1817), a youthful work, is an ode that holds onto the ideal of the ancien régime while exhibiting all the symptoms of the incumbent dissolution of a monarch-centered poetics. Eschew-

PMLA 70, no. 5 (1955): 1033-1048, esp. 1047-1048. His Sonnets Dedicated to Liberty (1807) merit separate discussion.

36. In the manuscript of the poem, Shelley transcribed lines 95-97 from Pythian 8 . Nancy Goslee, Shelley's Visual Imagination (Cambridge: Cambridge University Press, 2011), 126 (based on the original observation by Adamson).

37. William Levine, "Collins, Thomson, and the Whig Progress of Liberty," Studies in English Literature, 1500-1900 34, no. 3 (1994): 553-577, esp. 565. Collins may have also known Maciej Kazimierz Sarbiewski’s militaristic Ad Libertatem. Canovan discusses Joseph Priestley's progressivist notion of Liberty, which she contrasts with the degraded vision of society assumed in John Brown's classicizing account. Margaret Canovan, "Two Concepts of Liberty-Eighteenth-Century Style," Price-Priestley Newsletter 2 (1978): 27-43, esp. 31-33.

38. Levine, "Collins," 570. 
ing a direct address to the sovereign or an anchor in the occasion, the poem begins aggressively- "I wish to proclaim in song Liberty to the world, and defeat the vice that took its seat on Thrones ... The tyrants of the world, tremble! But take courage and listen, slaves, and rise from your knees!" (Хочу воспеть Свободу миру, / На тронах поразить порок ... Тираны мира! трепещите! / А вы, мужайтесь и внемлите, / Восстаньте, падшие рабы!) - only to proffer a contrast between legitimate autocracy and lawless tyranny, subscribing to a tradition that goes back to Hellenistic theories of kingship. Liberty's seemingly overwhelming dynamism is ultimately brought to an implausible standstill: should the monarchs learn to obey the Law, "the Liberty and Peace of nations shall be on eternal duty as the Throne's guard" (И станут вечной стражей трона / Народов вольность и покой). This eternity, however, proved provisional, not providential. Eight years later, the failed Decembrist revolt (1825), a high point of republican political action in Russia, confirmed a decisive conceptual divorce between Liberty and monarchy.

\section{Radical Pindarics in the 1780s: Radishchev and Schiller}

The eve of the French Revolution produced two highly experimental Pindaric odes, one by a Russian and another by a German poet: Liberty (Vol'nost', 1781-1783) by Alexander Radishchev and [Ode] to Joy (An die Freude, 1785, published in 1786) by Friedrich Schiller. Both poems, while often seen as artistically deficient, enjoyed a remarkable afterlife. ${ }^{39}$ Whereas Schiller's text, set to music in the finale of Beethoven's Ninth Symphony, came to stand for the unapologetic triumphalism of the First World, Radishchev's poem was valorized in the Soviet period as the originating moment in the Russian revolutionary tradition.

Radishchev's Liberty, a poetic response to the American Revolutionary War, lacks obvious precedents. ${ }^{40}$ In Germany, where Radishchev studied in the 1760s and with whose poetic culture he was well acquainted, events in

39. Schiller deemed "An Die Freude" a "bad" poem (ein schlechtes Gedicht), although he acknowledged that because it responded to a "mistaken taste of the time" (fehlerhaften Geschmack der Zeit), it became "in a way a folk poem" (gewissermaßen ein Volksgedicht). Schillers Briefwechsel mit Körner: Von 1784 bis zum Tode Schillers [Schiller's correspondence with Körner: From 1784 until Schiller's death], vol. 4 (Leipzig: Veit, 1859), 196, 21 October 1800. Pushkin had a low opinion of Radishchev's poetic abilities (see his 1836 piece "Aleksandr Radishchev").

40. See Grigory Gukovsky's commentary in A. N. Radishchev, Polnoe sobranie sochinenii [Complete collected works], vol. 1 (Moscow: AN SSSR, 1938), 444. The text of Vol'nost' is cited from the same edition (1-17). 
Britain's American colonies called to life at least one hymnic text that allegorized freedom, Christian Schubart's Freiheitslied eines Kolonisten, published in 1787, which substitutes Freedom for a military commander who inspires self-sacrifice:

The goddess Freedom with the flag

(Which the slave never saw)

Walks-brothers, look! She walks in front!

O do shed blood for her! ${ }^{41}$

Schubart also wrote Deutsche Freiheit, summoning Liberty to bring about peace and unity to Germany (also published in 1787) and An die Freiheit (1789), a reaction to the French Revolution. All these texts postdate Radishchev's poem and lack its massive size and thematic scope (Liberty comprises fifty-four ten-line stanzas), yet they speak to the vitality, at that time, of the odic device of allegorizing Liberty. The earliest such text known to me is Ad Libertatem by Casimire Sarbiewski, the "Polish Pindar," who was influential both on the Continent and in Britain. ${ }^{42}$ Radishchev's acquaintance with Collins's Ode to Liberty is unlikely. Johann Uz also wrote an ode "An die Freyheit" (1776). ${ }^{43}$ One should also note Radishchev very likely knew Rousseau's Ode to Fortune. ${ }^{44}$

None of these poems, however, comes close to the radicalism of Radishchev's Liberty, in which the monarchical principle is rejected with violent resolution. For instance, the only credit Radishchev grants to Augustus, the epitome of a just ruler in Rousseau's poem, is that he "has at least covered his beastliness with kindness" (прикрыл хоть зверство добротою), for "no monarch was ever equitable!" (Но царь когда бесстрастен был!) Surprisingly from the viewpoint of the British "progress poem" tradition, no positive examples of republican governance are cited. Thus, Cromwell is deemed "a villain" because he suppressed freedom, yet he is praised for "teaching nations how to avenge themselves: you put Charles on trial and executed him." Instead of tracing Liberty's career, Radishchev redefines it as

41. "Die Göttin Freiheit mit der Fahn - / (Der Sklave sah sie nie) / Geht - Brüder, seht! sie geht voran! / O blutet für sie!” Deutsche Gedichte des 18. Jahrhunderts [German poems of the eighteenth century], ed. Klaus Bohnen (Stuttgart: Reclam, 1987), 345.

42. Revard, Politics, 87-93.

43. Johann Peter Uz, Sämmtliche poetische Werke [All poetic works], vol. 1 (Karlsruhe: Schmieder, 1776), 212-214.

44. Viktor M. Zhivov, “Apokalipsis svobody: Zametki ob ode "Vol'nost”" A. N. Radishcheva" [The apocalypse of freedom: Notes on the "Vol'nost" ode by A. N. Radishchev," in Venok: Studia slavica Stefano Garzonio sexagenario oblata [Venok: Slavic studies in honor of Stefano Gerzonio], vol. 1, ed. Guido Carpi, Lazar Fleishman, and Bianca Sulpasso (Stanford, CA: Stanford University Press, 2012), 75-85, esp. 78-79. 
the obverse of religious superstition (citing Luther) and equates it with the triumph of an enterprising, rational modernity (citing Columbus and Galileo). Thus, Liberty is effectively depoliticized, sublimated as "the creative spirit of Freedom." Indeed, the cycle of liberation and enslavement is inescapable, as the reconstitution of the prelapsarian "natural order of things" (естественной встает устав) results in Hobbesian violence that can only be averted by a social contract, which is, in turn, eventually breached by a tyrant. Instead of a positive sociopolitical program, Viktor Zhivov notes, we find in Radishchev a messianic anticipation of a different world order, brought about by the Second Coming. ${ }^{45}$ This utopian idea, demanding the transfiguration of the body of the nation, however, is not unique to this poem. As suggested by parallels from Marvell and Schiller, it is symptomatic of the republican retelling of the early modern Pindaric myth of subduing the monstrous.

A decisive overhaul of the traditional poetics of power is a self-conscious objective in Liberty. First, Radishchev pries apart the tripartite nexus uniting the monarch, God, and the community:

When we look at the expansive regions,

Where a lackluster throne of slavery stands,

Civil powers are all at peace there,

Since they see in the monarch an image of divinity.

The Royal power preserves the faith.

Faith confirms the Royal power.

United, they oppress the society.

One attempts to chain the reason,

The other to obliterate the will:

Both for the common good-they say. ${ }^{46}$

Radishchev's agenda, however, is not secularist. Instead, drawing a distinction between a misconstrued and a true Christianity, he claims to celebrate in his "victory song" the recognition of the true nature of the deity, which is no longer confused with the monarch:

God no longer is seen in an alien form,

Nor does he avenge his insult,

But is spread out in his activity.

We sing our victory song

Not to one who rescued us from apparent troubles,

But to the Eternal Father of all that is visible.

45. Zhivov, “Apokalipsis,” 86.

46. The text of the poem is cited from Radishchev, Polnoe sobranie sochinenii, 1-17. 
Correctly construed and thoroughly dehumanized, the divine is manifested in the spirit of Liberty that the ode is celebrating: "Great, great is the spirit of Freedom, and creative, as God himself!” (Велик, велик ты дух свободы, Зиждителен, как сам есть бог!) The logic of this substitution is dictated by the inherited poetics of the Pindaric ode in which the hymnic addressee, even if it represents an abstraction with no specific cult associations, assumes quasi-divine attributes by virtue of being personified.

The other polemical intent of Liberty is to undo the political mainstay of the ancien régime: the view of the monarch as a figure for the body politic in its positively valued active hypostasis. The heroic agent, and the embedded speaker of the poem, is the personified "People" itself (narod), which takes it upon itself to unseat the monarch:

But you, having forgotten the oath you gave me, Having forgotten that it was me who elected you

To be crowned for my delectation,

Have imagined that you are the lord, not me.

How can a sovereign nation exist without its will being represented by a ruler? Radishchev's response to this dilemma is in keeping with Rousseau's Du contract social: the rule of the "Spirit" (of Liberty) demands a redefinition of the individuated subject as a communal "we." As Yuri Lotman shows, in Liberty Radishchev departs from his more usual Helvetian views and follows Rousseau in allowing the communal will to override individual freedom. ${ }^{47}$ Yet, ideally, no gap exists between one's own and the common will: "There are no barriers to the common good; I see my share in the power of all; Following my will, I follow the will of all; in society, Law is born" (Для пользы общей нет препон; Во власти всех своей зрю долю, Свою творю, творя всех волю; Родился в обществе закон).

While this peaceful state of equilibrium is transitory-the cycle of revolution demands that any republic fail-it gives us a foretaste of a different world order. For a brief moment, art and science are in bloom, since they most eloquently manifest the spirit's freedom, or the Spirit of freedom. Such semantic and syntactic fluidity is a token of the liberation of abstractions from the logic of narrative, and indeed from that of personification:

The crown, placed on Pindar, is weaved by art's hand.

The crown, weaved by science, is worn on Newton's head.

47. Yuri Lotman, "Radishchev i Mabli," in Izbrannye stat'i [Selected articles], vol. 2 (Tallinn: Aleksandra, 1992), 100-123, esp. 116. 
Thus, always fancying about itself, carried aloft on the wings of reason, The spirit, agile and firm, is omnipotent. [It will traverse the universe.] It will be elevated to the edge of the worlds.

We are its object, not $\mathrm{I}^{48}$

The new sovereign-“we, the people"-becomes the agent of the ensuing narrative that takes the place of the myth of the earlier Pindaric ode. All of a sudden, a monster-the Other of the newly constituted nation-arrives to upset the harmonious state just described. Not named as a tyrant, it is rather a conceptual aggregate of all that must be rejected to make way for a new politics: superstition, flattery, defiance of rationality, a pretense to divine provenance, a show of sentimentalism, outright deceit, corruption, and uncontrollable self-propagation ("hundred-headedness").
And lo-a horrific monster,
Hundred-headed like a hydra,
Sweetly-speaking and always in tears,
Yet with jaws filled with poison,
Tramples on earthly powers,
Reaches for heaven with its head -
This is where its fatherland is, it proclaims, -
Spreads phantasms and darkness everywhere,
Knows how to deceive and to flatter,
And bids us to believe blindly.

The overcoming of the hydra of the past by Liberty is the republican version of the Pindaric myth. Radishchev's ode retains two of the key formal elements of the early modern poetics of ancien régime: the struggle with the monstrous Other as a moment of community's self-constitution, and the alliance of this community with a divine agent that intervenes in human history. Yet, Radishchev places them in a temporality that is ostensibly at odds with that of linear progress. Operating with a premodern (Polybian) time of cyclic "re-volution," Liberty valorizes one phase of the cycle as a token of the harmonious stasis projected into an indefinite, apocalyptically colored future.

Schiller's An die Freude (1786) puts forward a post-monarchist poetics that is both less overtly political than Radishchev's and more thorough in its

48. “Венец, Пиндару возложенный, / Художества соткан рукой; /Венец, наукой соплетенный, / Носим Невтоновой главой; / Таков, себе всегда мечтая, / На крыльях разума взлетая, / Дух бодр и тверд возможет вся; / [По всей вселенной пронесется;] / Миров до края вознесется: / Предмет его суть мы, не я.” 
revision, or reduction, of the genre's original schema. Indeed, while the view of Schiller's poem as a call for rebellion appears to be in many ways a product of its later reception, "Liberty" and "Joy" are not only kindred concepts; from the viewpoint of their function in the genre's schema, they are equivalent. Indeed, there exists a minority view that a prepublication version of $A n$ die Freude addressed Freiheit rather than Freude.$^{49}$ What made Schiller's text basically compatible with a republican reading was the ongoing transformation of the inherited poetics of the Pindaric ode.

Stylized as a cult processional hymn, which merges the "I" of the poet and the "we" of the chorus, An die Freude favors a ritualistic, rather than a philosophical, stance. Once the community, expanded to include the entirety of humanity, enters the "sanctuary of Joy," it can experience a kind of festive union that-in a primitive, Durkheimian fashion-attests to the existence of a divine "dear father" shared by all. In a conceptual and temporal move similar to the one we observed in Radishchev's Liberty, Joy becomes a proxy deity that signifies, or gestures toward, full divine presence. Temporal distance is here figured by spatial distance:
Embrace, millions!
A kiss to the entire world!
Brothers, beyond the firmament of stars
there must reside a dear father..$^{50}$

In contrast to Radishchev's Christianized "spirit" of Liberty that has a recognizable historical dimension (albeit not a full-fledged career of Collins's Liberty), Schiller's "Joy" is the indwelling force of celebration that obliterates history, making all living creatures recognize mutual kinship. Glossed as cosmic "Sympathie" - a notion reaching back to Stoicism-it is, first and

49. See Christoph Bruckmann, “'Freude! Sangen wir in Thränen, / Freude!' In dem tiefsten Lied: Zur Interpretation und Rezeption des Gedichts An die Freude von Friedrich Schiller" ["Joy! We sang in tears, joy!" In the deepest song: Toward the interpretation and reception of the poem An die Freude by Friedrich Schiller] Jahrbuch der deutschen Schillergesellschaft 35 (1991): 96-112, esp. 108-110. The arguments presented by Uwe Martin in favor of an early redaction are not compelling. Uwe Martin, "Im Zweifel für die Freiheit: Zu Schillers Lied An die Freude" [When in doubt, favor freedom: On Schiller's song An die Freude] Germanish-romanische Monatsschrift 48, no. 1 (1998): 47-59. On the reception of the poem, see Gail K. Hart, "Schiller's 'An die Freude' and the Question of Freedom," German Studies Review 32, no. 3 (2009): 479-493.

50. "Seid umschlungen, Millionen! / Diesen Kuß der ganzen Welt! / Brüder - überm Sternenzelt / Muß ein lieber Vater wohnen." The text of the poem is cited from Friedrich Schiller, Werke in drei Bänden, vol. 1, ed. Gerhard Fricke and Herbert G. Göpfert (Darmstadt: Wissenschaftliche Buchgesellschaft, 1984), 47-50. 
foremost, an emblem, a totem that mirrors the self: ${ }^{51}$ addressing "Joy" is a way of addressing the community. The sociopolitical underpinnings of this unity are clear in the promise of "beggars becoming prince's brothers" (Bettler werden Fürstenbrüder) and, in the final stanza, of "the delivery from tyrants' chains" (Rettung von Tyrannenketten). Yet, Schiller advises patience, and-similarly to Radishchev and, much earlier, Marvell ${ }^{52}$ - couches the expectations of a different world in the millenarian language.

Endure bravely, millions!

Endure for a better world.

Over there, beyond the starry firmament,

A great God will reward you. ${ }^{53}$

Schiller's text does not include a narrative component. The modern ritual that the poem enacts, rather than evoking past exempla, points to humanity's soteriological future. The basic epinician plot is nevertheless retained: "brothers" are invited to pursue their path "joyously, as a hero toward a victory" (Laufet, Brüder, eure Bahn, / Freudig, wie ein Held zu Siegen). A revealing aspect of Schiller's poem, and one that is symptomatic of Western modernity, is that the Other, that over which the hero is supposed to triumph, is suppressed. The making of a better world is achieved by the mere overcoming and forgetting of the past, which is cast, in the Pindaric spirit, as the realm of oppression and vengeful violence:

Let Anger and Revenge be forgotten;

A deadly enemy forgiven;

No tear shall oppress him,

No remorse bite him. ${ }^{54}$

Compared to Radishchev's Liberty, the Ode to Joy further dismantles the Pindaric schema, in that it does away not only with the junction "mon-

51. Garty M. Gurtler, "Sympathy: Stoic Materialism and the Platonic Soul," in Neoplatonism and Nature: Studies in Plotinus' Enneads, ed. Michael F. Wagner (Albany: State University of New York Press, 2002), 241-276. Further, on the connotations of Freude in the context of late eighteenth-century Germany and the significance of the masonic hymn as a generic precedent for Schiller, see Bruckmann, "Freude!" 97-100.

52. "For the great Justice that did first suspend / The World by Sin, does by the same extend. / Hence that blest Day still counterpoysed wastes, / The ill delaying, what th' Elected hastes.” First Anniversary Ode.

53. "Duldet mutig, Millionen! / Duldet für die beßre Welt! / Droben überm Sternenzelt / Wird ein großer Gott belohnen.”

54. "Groll und Rache sei vergessen,/ Unserm Todfeind sei verziehn. / Keine Thräne soll ihn pressen, / Keine Reue nage ihn.” 
arch-God-community" but also with the opposition between Self and Other. On the ruins of the traditional poetics, there remains standing the numinous abstraction, a collective singular energized by expectation and calling for universal allegiance.

\title{
Concluding Remarks: Liberty and Community
}

Radishchev's and Schiller's odes share a particular pattern of interaction between their focus concept, which I termed the proxy deity, and community. The abstract notions of Liberty and Joy allow not only for a reconceptualization of the divine hymnic addressee but also for a new construal of the self, processual rather than centered on a heroic feat: thanks to Liberty's (or Joy's) benign effect, all are morally or spiritually improved. The same pattern can be detected in early poems addressing abstract concepts. For example, in Casimire Sarbiewski's Ad libertatem (Odes 4, 38), the Polish Liberty makes citizens more virtuous:

\author{
Public virtue \\ Shone forth brighter through all classes, \\ When the great shade of Liberty \\ Covered both the scepters and the people..$^{55}$
}

Similarly, in Johann Uz's "An die Freyheit," "each citizen is thinking lofty thoughts when animated by your [Freedom's] fire" (Beseelt von deinem Feuer, / Denkt jeder Bürger groß). ${ }^{56}$ This educational, or at any rate civic, dynamic is not part of the canonical schema of the early modern Pindaric. It is made possible by a relocation of the divine force, no longer concentrated in the heroic sovereign but instilled in the citizen body, at once as an abstraction and as individual affect.

55. "Publica clarius / Virtus per omnes emicuit gradus, / Cum magna Libertatis umbra / Sceptra simul populumque texit." In John Bowring's translation, published in 1827: "And in there aught so purely bright, / as when in truth and virtue's light / Impartial Freedom deigns to shed / Her joys on prince and people's head." Casimir Britannicus, English Translations, Paraphrases, and Emulations of the Poetry of Maciej Kazimierz Sarbiewski (London: Modern Humanities Research Association, 2008), 226. Inasmuch as liberty is aligned with lawfulness, it can be argued to be in the interest of the monarch, as in Pushkin's Liberty, where the same image of law as shared protection recurs: "People's suffering does not lie imposed on royal head only there where the link between sacred liberty and powerful laws is strong, where their strong shield is extended for all." (Лишь там над царскою главой / Народов не легко страданье, / Где крепко с вольностью святой / Законов мощных сочетанье; / Где всем простерт их твердый щит.)

56. Uz, Sämmtliche poetische Werke, 213. 
Furthermore, for both Radishchev and Schiller, the future-for Pindar, the great unknown-becomes an indispensable part of their odic poetics, in keeping with Koselleck's analysis of future-oriented modern concepts, in which expectation takes the place of experience. As the progress of Joy or Liberty comes to replace the traditional plot of the struggle with the Other, the semantics of these abstractions is rendered moot; in some cases, they become mere signifiers of collective identity. At an extreme, evoked in Schiller's An die Freude, they come to operate as totems, which are chosen arbitrarily as an image in which the particular group of people recognizes itself as a community. Notably, Émile Durkheim compares totems to emblems or national flags in modern societies; in both cases, a random material referent accumulates the social energy of self-identification. ${ }^{57}$

An archaizing interpretation of modern collective concepts is explored in the ample commentary on the nonsynchronous quality of European modernity, much of it emerging from the German and Russian intellectual milieus and often focusing on the concept of liberty. In contrast to the "liberal" and "republican" traditions, which emphasize, respectively, lack of interference and lack of domination, a "Hegelian" tradition understands liberty as a function of community. Most memorably, Ernst Troeltsch's 1916 essay "Die deutsche Idee von der Freiheit" draws a contrast between the "Western" (Anglo-American and French) and the German concepts of freedom: whereas the former arose out of "civil democracy" and capitalism, the latter is conditioned by Germany's pristine, "medieval-estate-agrarian being." 58 The delayed arrival of humanism did not prevent Germany from overtaking its Western counterparts in philosophical, scientific, and artistic domains. These spiritual achievements have molded the German idea of freedom, which Troeltsch, relying on Hegel, defines as "free, conscious, duty-induced dedication to a totality that has already been constituted by history, the state, and the nation." 59

Commenting on Troeltsch's contrast between two kinds of freedoms, Louis Dumont points out ${ }^{60}$ that it coincides with the one between $G e$ sellschaft (society) and Gemeinschaft (community), an opposition of fundamental importance for not only the German but also the Russian nationalist

57. Émile Durkheim, The Elementary Forms of Religious Life (Mineola, NY: Dover, 2008), 220.

58. Ernst Troeltsch, "Die deutsche Idee von der Freiheit" [The German idea of freedom], in Deutscher Geist und Westeuropa (Tübingen: Mohr, 1925), 80-107, here 83 ("mittelalterlich-ständisch-agrarisches Wesen”).

59. Ibid., 88, quote on 94 ("die freie, bewußte, pflichtmäßige Hingabe an das durch Geschichte, Staat und Nation schon bestehende Ganze").

60. Louis Dumont, Essays on Individualism: Modern Ideology in Anthropological Perspective (Chicago: University of Chicago Press, 1986), 145. 
discourse, prone to denouncing the excesses of Western individualism. ${ }^{61}$ The communitarian ideal can even be seen to underlie the Marxist notion of freedom as conditioned by a collective project of building a classless society. In 1937, Nikolai Berdyaev noted that Bolshevism, of which he was highly critical, "rechanneled the religious energy" of Christianity. He had no doubt that communism, a reaction to the atomization of humanity under the bourgeois-capitalist order, is truer to the Christian ideal than capitalism. ${ }^{62}$

Koselleck should also be counted among the intellectuals vexed by the semiotic regime of modernity. His early Critique and Crisis puts forward a vehement attack on the Enlightenment and an implicit Schmittian defense of the ancien régime. ${ }^{63}$ On its own terms, Hans Blumenberg's work presents a consistent repudiation of the notion of modern age as a time protected from the tenacious hold of myth. From its origins, conceptual history is thus intertwined with a critique of modernity's totalizing claims, a critique that seeks to assure that at the entrance to "the sanctuary of Joy" one is not stripped of history, understanding, and stories to tell. For that kind of project, literature is indispensable.

The history of the Pindaric ode suggests that even the most unambiguously emancipatory political abstraction, Liberty, can take on various guises, some of them quite illiberal. A grasp on the matrix of the Pindaric allowed us to see the force of modern concepts as an extension of the genre's earlier functions. Not only is freeing the individual from the collective itself a collective ideal; this ideal is conveyed by conceptual means that reach back to Europe's premodern past as well as exhibit a typologically widespread emblematic structure. Where, amid these meandering itineraries, a viable path lies, is a question that history of concepts, once it equips itself with the toolkit of Historical Poetics, may be better placed to answer.

Boris Maslov is Associate Professor of Classical Languages at the University of Oslo.

Email: b.r.maslov@ifikk.uio.no.

61. Examples of such critique include Dostoevsky's Winter Notes on Summer Impressions (1863) and Solzhenitsyn's A World Split Apart (1978).

62. Nikolai A. Berdiaev, Istoki i smysl russkogo kommunizma [The origins and meaning of Russian communism] (1937; repr., Moscow: Nauka, 1990), 139 (quote), 150-151. For a trenchant critique of this argument, see Viktor Zhivov, "O somnitel'nom i nedostovernom v istoriosofii N.A. Berdiaeva" [On what is dubious and unreliable in N. A. Berdiaev's philosophy of history] Novyi mir, no. 10 (1990): 216-222.

63. Reinhart Koselleck, Critique and Crisis: Enlightenment and the Pathogenesis of Modern Society (Cambridge, MA: MIT Press, 1988). 